RESEARCH REPORT

\title{
Lifecourse study of bone health at age 49-51 years: the Newcastle thousand families cohort study
}

\author{
Mark S Pearce, Fraser N Birrell, Roger M Francis, David J Rawlings, Stephen P Tuck, Louise Parker
}

J Epidemiol Community Health 2005;59:475-480. doi: 10.1136/jech.2004.025999

See end of article for authors' affiliations

.....................

Correspondence to:

Dr M S Pearce, Sir James

Spence Institute of Child Health, University of Newcastle upon Tyne, Royal Victoria Infirmary, Newcastle upon Tyne, NE1 4LP, UK; m.s.pearce@nd. ac.uk

Accepted for publication 3 January 2005
Objective: To quantify the direct and indirect effects of fetal (position in family, weight, and social class at birth), childhood (breast feeding, growth, infections, and social class in childhood, age at menarche), and adult life (social class, alcohol consumption, smoking, diet, reproductive history, exercise, hormone replacement therapy use), and adult size (height, weight) on bone health at age 49-51 years, as measured by bone mineral density, total scanned bone area of the hip and lumbar spine, and femoral neck shaft angle.

Design: Follow up study of the Newcastle thousand families birth cohort established in 1947.

Participants: 171 men and 218 women who attended for dual energy $x$ ray absorptiometry scanning.

Main results: Fetal life explained around $6 \%$ of variation in adult bone mineral density for men, but accounted for less than $1 \%$ for women. Adult lifestyle, including effects mediated through adult weight accounted for over $10 \%$ of variation in density for men and around $6 \%$ for women. Almost half of variation in bone area for men was explained by early life. However, most of this was mediated through achieved adult height and weight. In women, less than $5 \%$ of variation in bone area was accounted for by early life, after adjusting for adult size. Most of the variation in each of the indicators for both sexes was contributed either directly or indirectly by adult lifestyle and achieved adult height and weight.

Conclusions: The effect of fetal life on bone health in adulthood seems to be mediated through achieved adult height.
$\mathrm{H}$ ealth in middle age has been proposed to be "programmed" by development in utero. ${ }^{2}{ }^{2}$ Recent studies suggest poor fetal and infant growth is associated with decreased skeletal growth and bone mass and an increased risk of osteoporosis and bone fracture in adulthood..$^{3-5}$ However, adult lifestyle factors, which affect the rate of bone mineral loss and hence fracture risk, ${ }^{6}$ may be more important predictors of adult bone health than fetal factors. It is also possible that factors in childhood, including periods of inactivity because of ill health, may affect future bone health.

The thousand families cohort ${ }^{7}$ provides an opportunity to investigate the fetal, childhood, and later life determinants of two indicators of bone health at age 49-51; bone mineral density (BMD) and bone area, and femoral neck shaft angle, an independent predictor of fracture risk. ${ }^{8}$ A lifecourse approach ${ }^{9}$ was used to estimate proportions of variance in these indicators explained by characteristics of fetal, infancy and childhood, and adult life and adult body size (height and weight at age 49-51).

\section{METHODS}

\section{Study participants}

The thousand families study began as a prospective study of all 1142 children born in May and June 1947 to mothers resident in Newcastle, UK. ${ }^{10}$ Participants were members of the cohort who were either traced through the NHS Central Register or contacted the study team in response to media publicity. Between October 1996 and December 1998, health and lifestyle questionnaires were sent out for completion and return and study members invited to attend for clinical examination that took place over the same time period.

Of the original cohort, 832 ( $86 \%$ of the surviving sample of 967 children whose families remained in Newcastle for at least the first year of the study) were traced at age $49-51 .{ }^{11}$ Of these, 574 completed the health and lifestyle questionnaire and 389 (171 men and 218 women) underwent dual energy $x$ ray absorptiometry.

\section{Clinical assessment of outcome and adult height and weight}

Indicators of bone health (BMD and area of the hip and spine, and femoral neck shaft angle) were measured using a Hologic QDR 2000 machine (Hologic Instruments, Waltham, MA, USA). Height and weight were also measured at this time. The scanning machine had a coefficient of variation of $0.5 \%$ throughout the period of study. A measure of bone area was derived by adding the total bone areas of the lumbar spine and hip. The femoral neck shaft angle was measured (by SPT and DJR), directly from the BMD scan printout using a method adapted from that previously published. ${ }^{12}{ }^{13}$ The measurement of femoral neck shaft angle had an intraobserver error of $0.79 \%$, interobserver error of $1.2 \%$, and precision of $\pm 1.2 \%$.

Explanatory variables were grouped within a conceptual framework, ${ }^{14}$ according to the lifecourse stage at which they would be expected to influence future bone health (fig 1). This approach allows the individual effects of variables on bone health in later life to be examined, while also giving the opportunity for an overall effect of factors operating at a similar stage in a person's life to be investigated.

\section{Measurement of early life experience}

Information on early life was recorded prospectively for all study members and is described in detail elsewhere. ${ }^{10} 111516$ Birth weights, as recorded by the midwife, were standardised for gestational age and sex. ${ }^{17}$ Socioeconomic status at birth was measured by paternal occupational social class and at age 5 years by that of the main wage earner in the household. Duration of breast feeding was defined as the length of time an infant was at least partly breast fed. Position in family was calculated from the number of older surviving siblings, including half siblings. ${ }^{10}$ Age at menarche was recorded in the questionnaire at age 49-51, a method that has previously been shown to be reliable. ${ }^{18}$ Growth in early childhood was measured as the difference in standard deviation scores for 


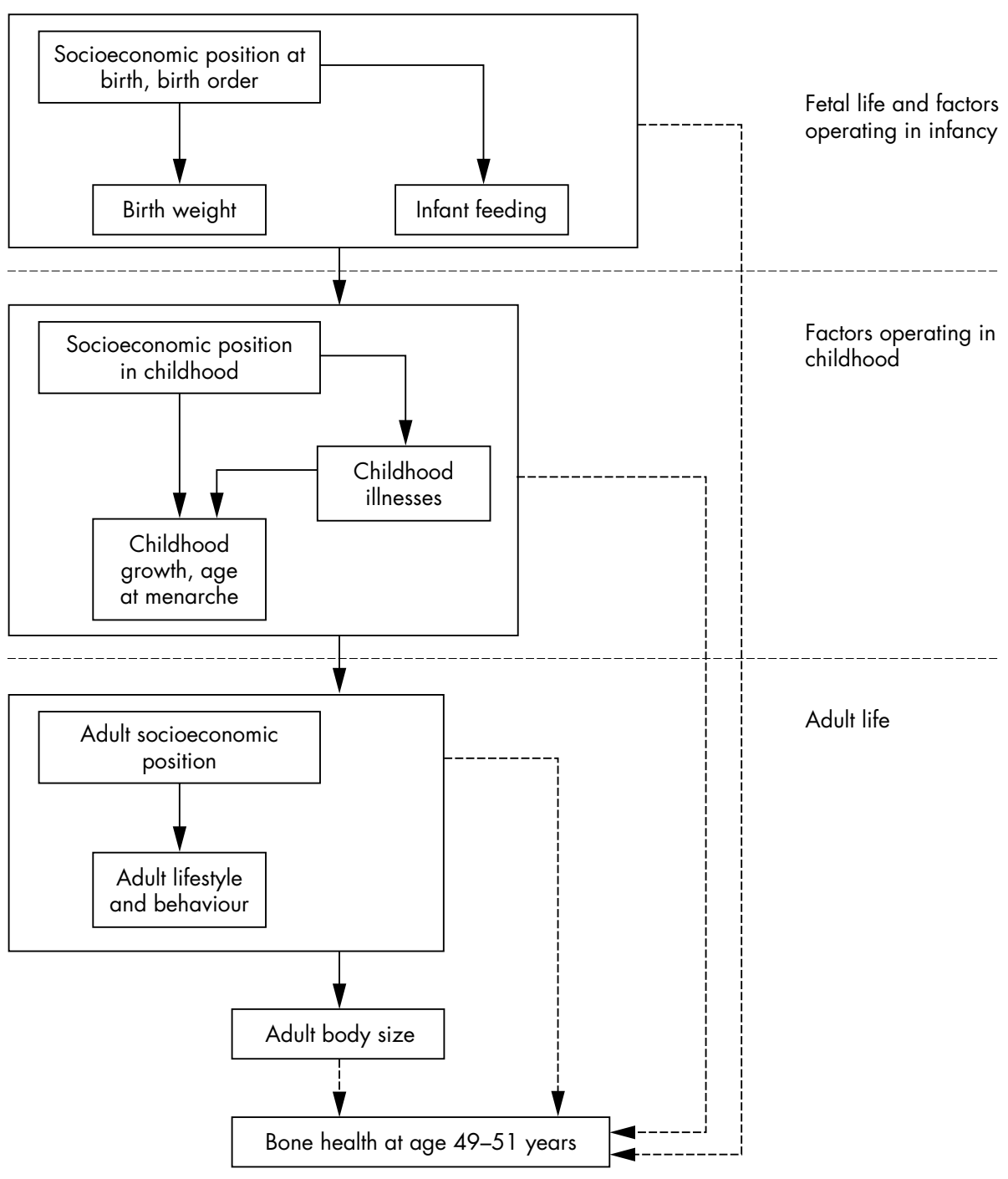

Figure 1 Conceptual framework for fetal, infant, childhood, and adult influences on bone health at age 49-51 years. The dashed lines are direct effects of each stage of the lifecourse on bone health; the solid lines are indirect effects mediated through later stages of the lifecourse.

birth weight and height at age 9 years. Illnesses were notified to the study team by the health visitors, parents, general practitioners, and from hospital referrals and attendances. For study members with complete follow up to age 15, the total number of episodes of acute illnesses (appendicitis, Bornholm's disease, chicken pox, eye disorders, hepatitis, influenza, measles, meningitis, mumps, rubella, scarlet fever, shingles, whooping cough, and other acute infections) from birth up to the age of 15 was recorded, as was the presence of at least one chronic illness (anaemia, asthma, chronic respiratory disease, chronic ear infection, glandular fever, gout, other lung or respiratory disease, nephritis, polio, tuberculosis) during the same period.

\section{Measurement of adult socioeconomic position and lifestyle}

Occupational social class of the main wage earner in the household, the number of pack years of cigarettes smoked, alcohol consumption, dietary information, number of pregnancies (the total number of her live births, stillbirths, terminations, and miscarriages) and the use of hormone replacement therapy were derived from the returned self completion questionnaire data at age $49-51 .{ }^{11}$ Light drinking, at age 49-51, was defined as up to five units/week of alcohol for women ( 10 units for men) and moderate drinking up to 21 units for women ( 28 units for men). ${ }^{19}$ The number of pack years of cigarettes smoked (one pack year $=$ one pack of cigarettes smoked per day for one year) was estimated from the study members' smoking habits at ages 15, 25, 35, and 50 , as ascertained at age 49-51. Dietary intake of vitamins C and D, protein, and calcium at age 49-51 were estimated from responses to the European prospective investigation of causes and nutrition (EPIC) food frequency questionnaire, ${ }^{20}$ included within the self completion questionnaire. Participants were ranked, and placed into quartiles, as to their daily intake. Physical activity assessment at age 49-51 was based on that used in the Medical Research Council's national survey of health and development. ${ }^{21}$ Hormone replacement therapy was defined as ever having received such treatment (up to age 49-51).

\section{Statistical analysis}

How representative participants in this study were in relation to the original cohort was tested using $\chi^{2}$ tests. Separate analyses were carried out by sex as BMD, skeletal size, and rates of bone loss are known to differ between men and women. Lifecourse effects on adult health have previously been shown to differ by sex for this and other cohorts. ${ }^{11} 2223$ Furthermore, the inclusion of variables such as age at menarche, and number of pregnancies prevents the use of a combined lifecourse model. Eleven twins were excluded from all analyses because of the differences in fetal development 
Table 1 Descriptive statistics for continuous variables by sex

\begin{tabular}{|c|c|c|c|c|}
\hline \multirow[b]{2}{*}{ Variable } & \multicolumn{2}{|l|}{ Men } & \multicolumn{2}{|l|}{ Women } \\
\hline & Number & Mean (SD) & Number & Mean (SD) \\
\hline \multicolumn{5}{|l|}{ Fetal life } \\
\hline $\begin{array}{l}\text { Birth weight }(\mathrm{kg})^{*} \\
\text { Infancy and childhood }\end{array}$ & 165 & $3.42(0.47)$ & 212 & $3.38(0.51)$ \\
\hline Duration of breast feeding (months) & 163 & $3.99(3.90)$ & 206 & $3.94(3.91)$ \\
\hline Age at menarche (years) & - & - & 194 & $13.0(1.50)$ \\
\hline $\begin{array}{l}\text { Number of acute infections in childhood } \\
\text { (up to age } 15 \text { years) }\end{array}$ & 142 & $16.3(8.14)$ & 177 & $15.9(6.96)$ \\
\hline $\begin{array}{l}\text { Childhood growth (change in } \mathrm{z} \text { scores: } \\
\text { birth and } 9 \text { years) } \\
\text { Adulthood }\end{array}$ & 129 & $-0.59(1.34)$ & 160 & $-0.77(1.36)$ \\
\hline $\begin{array}{l}\text { Lifetime cigarette smoking (pack years) } \\
\text { up to age } 49-51 \text { years } \dagger\end{array}$ & 109 & $24.4(16.8)$ & 113 & $16.6(11.2)$ \\
\hline Height at age $49-51$ years $(\mathrm{m})$ & 165 & $1.73(0.06)$ & 212 & $1.61(0.06)$ \\
\hline Weight at age $49-51$ years $(\mathrm{kg})$ & 165 & $81.4(13.0)$ & 212 & $69.4(14.1)$ \\
\hline Total adult dietary vitamin $\mathrm{C}(\mathrm{mg})$ at age $49-51$ years & 160 & $104.9(61.8)$ & 203 & $121.8(56.7)$ \\
\hline Total adult dietary vitamin $D(\mu g)$ at age $49-51$ years & 160 & $3.78(2.41)$ & 203 & $3.34(1.92)$ \\
\hline Total adult dietary protein $(\mathrm{g})$ at age $49-51$ years & 160 & $89.6(26.0)$ & 203 & $82.3(25.7)$ \\
\hline $\begin{array}{l}\text { Total adult dietary calcium (g) at age } 49-51 \text { years } \\
\text { Indicators of bone health at age } 49-51 \text { years }\end{array}$ & 160 & $988.2(331.1)$ & 203 & $951.4(312.5)$ \\
\hline Lumbar spine BMD $\left(\mathrm{g} / \mathrm{cm}^{2}\right)$ & 165 & $1.03(0.13)$ & 212 & $1.05(0.14)$ \\
\hline Total hip BMD $\left(\mathrm{g} / \mathrm{cm}^{2}\right)$ & 165 & $1.01(0.14)$ & 211 & $0.96(0.13)$ \\
\hline Bone area $\left(\mathrm{cm}^{2}\right)$ & 165 & $110.7(9.49)$ & 211 & $90.6(7.44)$ \\
\hline Femoral neck shaft angle (degrees) & 165 & $129.6(3.30)$ & 212 & $128.0(3.33)$ \\
\hline
\end{tabular}

*Birth weight standardised for gestational age and gender in all analyses, but unstandardised summary given in this table. †Excluding study members who had never smoked. SD, standard deviation.

for multiple births and the fact that data contributed by cotwins are not independent.

Chronic infection in childhood, hormone replacement therapy and physical activity were defined as binary variables. Social class, position in family, alcohol consumption, number of acute illnesses in childhood, quartiles of ranked adult dietary intake of vitamins C and D, protein and calcium, and number of pregnancies were defined as ordinal variables and assessed for trend. Other explanatory variables were treated as continuous variables. Fractional polynomials were used to investigate non-linear effects. $^{24}$

Table 2 Descriptive statistics for categorical variables by sex

\begin{tabular}{|c|c|c|c|c|c|}
\hline \multirow[b]{2}{*}{ Variable } & & \multicolumn{2}{|l|}{ Men } & \multicolumn{2}{|l|}{ Women } \\
\hline & & Number & $\%$ & Number & $\%$ \\
\hline \multirow[t]{3}{*}{ Social class at birth } & $\mathrm{I}, \mathrm{II}$ & 22 & 13.8 & 18 & 8.6 \\
\hline & III & 88 & 55.0 & 135 & 64.6 \\
\hline & IV,V & 50 & 31.3 & 56 & 26.8 \\
\hline \multirow{4}{*}{ Position in family } & lst & 87 & 52.7 & 107 & 50.5 \\
\hline & 2nd & 48 & 29.1 & 59 & 27.8 \\
\hline & $3 r d$ & 15 & 9.1 & 31 & 14.6 \\
\hline & $\geqslant 4$ th & 15 & 9.1 & 15 & 7.1 \\
\hline \multirow[t]{3}{*}{ Social class at age 5 years } & I,II & 30 & 20.1 & 39 & 20.9 \\
\hline & III & 66 & 44.3 & 76 & 40.6 \\
\hline & $\mathrm{IV}, \mathrm{V}$ & 53 & 35.6 & 72 & 38.5 \\
\hline \multirow{5}{*}{$\begin{array}{l}\text { Chronic infection in childhood } \\
\text { (up to age } 15 \text { years) } \\
\text { Social class at age } 49-51 \text { years }\end{array}$} & Yes & 81 & 49.4 & 123 & 58.3 \\
\hline & No & 83 & 50.6 & 88 & 41.7 \\
\hline & $\mathrm{I}, \mathrm{II}$ & 74 & 45.4 & 105 & 49.5 \\
\hline & III & 66 & 40.5 & 67 & 31.6 \\
\hline & IV,V & 23 & 14.1 & 40 & 18.9 \\
\hline \multirow{4}{*}{$\begin{array}{l}\text { *Alcohol consumption at age } \\
49-51 \text { years }\end{array}$} & None & 12 & 7.4 & 29 & 13.7 \\
\hline & Light & 62 & 38.0 & 88 & 41.7 \\
\hline & Moderate & 71 & 43.6 & 83 & 39.3 \\
\hline & Heavy & 18 & 11.0 & 11 & 5.2 \\
\hline \multirow{2}{*}{$\begin{array}{l}\text { Use of hormone replacement } \\
\text { therapy by the age of } \\
49-51 \text { years }\end{array}$} & Yes & - & - & 101 & 48.8 \\
\hline & No & - & - & 106 & 51.2 \\
\hline \multirow{8}{*}{$\begin{array}{l}\text { Physically inactive at age } \\
49-51 \text { years } † \\
\text { Number of pregnancies }\end{array}$} & Yes & 15 & 9.2 & 29 & 13.7 \\
\hline & No & 148 & 90.8 & 182 & 86.3 \\
\hline & 0 & - & - & 24 & 11.6 \\
\hline & 1 & - & - & 13 & 6.3 \\
\hline & 2 & - & - & 85 & 41.1 \\
\hline & 3 & - & - & 50 & 24.2 \\
\hline & 4 & - & - & 22 & 10.6 \\
\hline & $5+$ & - & - & 13 & 6.3 \\
\hline \multicolumn{6}{|c|}{$\begin{array}{l}\text { *Light drinking was defined as up to five units of alcohol per week for women ( } 10 \text { units for men) and moderate } \\
\text { drinking up to } 21 \text { units for women and } 28 \text { units for men. TSubjects were classed as physically inactive at age } 49 \text { - } \\
51 \text { years if they never walked more than one mile, did no heavy gardening, "do it yourself", cycling, sports, o } \\
\text { vigorous leisure activity, and if in work, did no strenuous activity. }\end{array}$} \\
\hline
\end{tabular}


Relations between indicators of bone health and explanatory variables were estimated using multiple linear regression. Standardised regression coefficients $(r)$, denoting the increase in each indicator of bone health for a standard deviation (SD) increase in the explanatory variable, are presented with accompanying 95\% confidence intervals. For the assessment of individual relations with indicators of bone health, study members with missing data were included in all analyses for which they contributed complete data.

Weight at age 49-51 was used to adjust BMD measurements for adult body size, because of the confounding effect of body and skeletal size on areal BMD. Similarly, weight and height were used to adjust the results for bone area. No adjustments were made for the analyses of femoral neck shaft angle as body or skeletal size have not been suggested to influence femoral geometry.

The percentage of total variance in each indicator accounted for directly by each lifecourse stage was estimated by the difference in $R^{2}$ between models with and without the group of variables in the lifecourse stage of interest (fig 1), including all other explanatory variables in the model. The overall effect of early life, including indirect effects mediated through factors operating in adulthood, was estimated by the value of $R^{2}$ from a model containing those variables operating in early life alone. The overall contribution of adult variables, including effects mediated through adult body size, was estimated by the difference in $R^{2}$ between models with and without this group of variables, and including all other variables except adult body size. All variables were included within this analysis. Only participants (115 men and 132 women) with complete data for all variables were included in this latter analysis.

\section{RESULTS}

This sample did not differ significantly $(p>0.05)$ from the 753 members of the original cohort not included in this analysis in terms of any of the factors in early life, except sex. There were more women in this sample than men compared with the original cohort $(\mathrm{p}<0.001$, results not presented).

Descriptive statistics for all variables are given in tables 1 and 2. All explanatory variables were considered for analyses of all four outcome variables. Only those statistically significant are discussed.

\section{Lifecourse influences on bone health \\ Fetal life}

Increased standardised birth weight was a significant univariate predictor of increased total bone area for both sexes $(p \leqslant 0.001)$, but after adjustment for adult height and weight remained significant for only the men (table 3 ). No other effect of birth weight was seen.

Earlier family position was a significant predictor of decreased hip BMD in men $(p=0.04)$, and remained so after adjustment for adult weight $(r=0.04,95 \%$ CI $0.00,0.08$, for a SD (1.75) increase in position in family, $\mathrm{p}=0.05$ ). For women, significant increases in femoral neck shaft angle were seen with increasingly advantaged social class at birth (SD 0.9) $(r=-0.60,95 \%$ CI $-0.14,1.04, \mathrm{p}=0.010)$. No other variables were associated with femoral neck shaft angle for either sex.

In men, fetal life directly accounted for between 5.2 and $7.7 \%$ of variation in outcome measures. In women, the effect of fetal life factors was smaller and directly explained less than $1 \%$ of the variation in BMD (table 4 ).

\section{Infancy and childhood}

Childhood growth was a significant univariate predictor of bone area for both men (SD 1.34, $r=2.21,95 \%$ CI 0.66, 3.76, $\mathrm{p}=0.005$ ) and women (SD 1.36, $r=1.66,95 \%$ CI 0.56, 2.76, $\mathrm{p}=0.003$ ), but was not independent of height and weight at age $49-51 \quad(\mathrm{p}>0.25)$.

In men, the overall contribution of all early life variables (fetal, infancy and childhood combined), including indirect effects mediated through later life, was to explain over $16 \%$ of the variation in BMD at both sites. Much less was explained in the women. For both sexes, nearly half of the variation in BMD explained by early life was mediated through adult height.

Almost half of all variation in bone area among the men was accounted for by early life variables, including their effects mediated through factors operating later in life, in particular adult height and weight. Less variation in bone area was explained by the overall effect of early life in women. For both sexes, most of the indirect effects involved seemed to be mediated through adult height and weight.

\section{Adult life}

In men, decreasing adult vitamin $\mathrm{C}$ intake was a significant predictor of decreased hip BMD (SD 1.12, $r=0.02$, 95\% CI $0.003,0.04, p=0.02$ adjustment for adult weight). Decreasing adult vitamin $\mathrm{C}$ intake was also significantly associated with decreased BMD of the lumbar spine ( $r=0.02$, $95 \%$ CI $0.00,0.04, p=0.05)$. However, this association was no longer significant after adjustment for adult weight $(\mathrm{p}=0.2)$. Self reported alcohol consumption at age 49-51 showed a significant association with bone area in men, which remained after adjustment for adult height and weight (SD $0.78, r=1.59,95 \%$ CI $0.55,2.62, \mathrm{p}=0.003)$. Additional adjustment for waist circumference or physical activity at age 49-51 or socioeconomic status at any age did not affect this result (not presented).

In women, an association was seen between number of pregnancies and hip BMD (SD 1.34, $r=0.02$, 95\% CI 0.002, $0.04, p=0.026)$ although this was of reduced significance after adjustment for adult weight $(\mathrm{p}=0.05)$.

Most of all the explained variation in the indicators of bone health at age 49-51 in both sexes was contributed either directly or indirectly by adult lifestyle and adult body size. Greater proportions of variation in BMD were explained directly by adult weight for women than men.

Table 3 Relation between birth weight and bone health, before and after adjustment for adult body size (standardised regression coefficients and corresponding $95 \%$ confidence intervals) by sex

\begin{tabular}{lllll}
\hline \multirow{2}{*}{$\begin{array}{l}\text { Indicator of bone health at age } \\
\text { 49-51 years }\end{array}$} & Men & & Women \\
\cline { 2 - 3 } & Unadjusted & Adjusted & & Unadjusted \\
\hline Total hip BMD $\left(\mathrm{g} / \mathrm{cm}^{2}\right)$ & $0.01(-0.01,0.03) \dagger$ & $0.00(-0.02,0.02)$ & & $0.01(-0.01,0.03)^{*}$ \\
Lumbar spine $\mathrm{BMD}\left(\mathrm{g} / \mathrm{cm}^{2}\right)$ & $0.02(0.00,0.04)$ & $0.01(-0.01,0.03)$ & $0.01(-0.01,0.03)$ & $0.00(-0.01,0.02)$ \\
Bone area $\left(\mathrm{cm}^{2}\right)$ & $2.57(1.15,3.98)$ & $1.11(0.04,2.18)$ & & $1.64(0.65,2.63)$ \\
Femoral neck shaft angle (degrees) & $0.29(-0.22,0.80)$ & - & $-0.24(-0.69,0.22)$ & $-0.01,0.02)$ \\
\hline
\end{tabular}

Adult size adjustments: weight for BMD; weight and height for bone area; no adjustments for femoral neck shaft angle. ${ }^{*}$ Result corresponds to a 0.01 (g/ $\mathrm{cm}^{2}$ ) increase in total hip BMD in men for a standard deviation change in standardised birth weight (where the standard deviation for standardised birth weight in men is 0.94 , and for women is 1.11 ). 
Table 4 Direct and overall contributions (given as percentages) to variance in indicators of bone health by sex at age 49-51 years from circumstances and experiences at each stage in the lifecourse

\begin{tabular}{|c|c|c|c|c|c|c|c|c|}
\hline & \multicolumn{4}{|l|}{ Men } & \multicolumn{4}{|l|}{ Women } \\
\hline & $\begin{array}{l}\text { Total hip } \\
\text { BMD }\end{array}$ & $\begin{array}{l}\text { Lumbar spine } \\
\text { BMD }\end{array}$ & $\begin{array}{l}\text { Bone } \\
\text { area }\end{array}$ & $\begin{array}{l}\text { Femoral neck } \\
\text { shaft angle }\end{array}$ & $\begin{array}{l}\text { Total hip } \\
\text { BMD }\end{array}$ & $\begin{array}{l}\text { Lumbar spine } \\
\text { BMD }\end{array}$ & $\begin{array}{l}\text { Bone } \\
\text { area }\end{array}$ & $\begin{array}{l}\text { Femoral neck } \\
\text { shaft angle }\end{array}$ \\
\hline \multicolumn{9}{|l|}{ Source } \\
\hline Fetal life (direct) & 6.9 & 5.2 & 7.0 & 7.7 & 0.1 & 0.7 & 2.6 & 4.4 \\
\hline Infancy and childhood (direct) & 2.9 & 5.0 & 5.6 & 7.3 & 1.6 & 1.7 & 1.9 & 2.9 \\
\hline Total early life (overall) & 16.7 & 18.0 & 48.5 & 8.9 & 7.0 & 4.6 & 31.5 & 5.9 \\
\hline $\begin{array}{l}\text { Total early life, excluding indirect } \\
\text { effects through adult size }\end{array}$ & 6.7 & 9.7 & 10.8 & - & 3.0 & 2.2 & 3.7 & - \\
\hline Adulthood (direct) & 10.6 & 8.3 & 4.6 & 5.6 & 3.4 & 5.9 & 3.0 & 7.4 \\
\hline $\begin{array}{l}\text { Adulthood overall, including } \\
\text { indirect effects through adult size }\end{array}$ & 13.9 & 9.8 & 2.8 & 5.6 & 6.1 & 5.8 & 3.9 & 7.4 \\
\hline Adult size (direct) & 7.7 & 5.3 & 11.6 & - & 24.1 & 10.0 & 12.7 & - \\
\hline${ }^{*}$ Total $R^{2}$ & 38.3 & 33.1 & 63.0 & 14.7 & 37.1 & 20.4 & 48.1 & 13.4 \\
\hline \multicolumn{9}{|c|}{$\begin{array}{l}{ }^{*} \text { Total } R^{2} \text { refers to the overall amount of variation in each outcome variable explained by all the explanatory variables included in this investigation. The overall } \\
\text { contribution of early life variables includes indirect effects mediated through adult socioeconomic position and lifestyle and adult body size. The overall contribution } \\
\text { of adulthood includes indirect effects mediated through adult body size. Adult size adjustments: weight for BMD; weight and height for bone area; no adjustments } \\
\text { for femoral neck shaft angle. }\end{array}$} \\
\hline
\end{tabular}

Fractional polynomial models provided little evidence for non-linear effects in any of the analyses presented.

\section{DISCUSSION}

\section{Principal findings}

While a univariate effect of birth weight was seen on bone area, the association was not independent of adult size. Similarly, much of the variation in bone area apparently explained by fetal factors seemed to be mediated through the correlation between adult size and bone area. Although the percentage of variation in bone health explained directly by factors in early life (and not explained by those mediating factors in later life considered) was small, it is probable that these effects would be explained by pathways not considered in this analysis. Factors in infancy and childhood explained little variation in any of the indicators of bone health investigated.

Adult lifestyle and body size accounted for a greater proportion of total variance in BMD and femoral neck shaft angle at age 49-51 than did the overall (but not mediated through achieved adult weight) contributions of early life. In particular, adult weight accounted for almost a quarter of the variation in hip BMD. Material sex differences were evident in proportions of variation explained, suggesting that the effects of factors at different stages of a person's life may vary between the sexes.

\section{Potential weaknesses}

Of 1142 people recruited at birth in 1947, 34\% participated in the study. Except for sex, the study sample was comparable for all explanatory variables in early life included in this investigation. In addition, inclusion of cohort members who had moved out of the study region increased the representativeness of the population studied.

\section{What this study adds}

In this follow up study of 171 men and 218 women born in Newcastle upon Tyne in May and June 1947, the relation between birth weight and skeletal growth has been confirmed. Previous studies have suggested a relation between fetal growth and future bone health. However, the effects of fetal growth and factors operating in early life seem to be mediated through achieved adult height and adult lifestyle.
Our inclusion rate, 50 years after the study began, is similar to that reported in some studies investigating the effects of early life factors on later health, ${ }^{25}$ and substantially greater than that reported in others. ${ }^{326}$

Experiencing childhood in a post-war environment, including rationing of food, may have resulted in reduced dietary variability than in pre-war birth cohorts, although this may make these results more relevant to immediate postwar birth cohorts.

A previous investigation using data from this cohort suggested that the dietary questionnaire may have resulted in the underreporting of dietary energy intake. ${ }^{11}$ Other studies have conversely noted an overreporting of energy intake, ${ }^{27} 28$ suggesting that results concerning dietary intake should be viewed with caution.

It was not possible to include all possible factors that may influence bone health in adulthood. For example, genetic factors, lifetime exercise, and sunlight exposure may have contributed to the variance not explained by our statistical models.

The women in this study were likely to be peri-menopausal; only a small number had early menopause. We were unable to examine the impact of menopausal status on bone health and the contribution of this to our findings. The sex differences in proportions of variance explained by different stages of life, are, however, likely to reflect hormonal factors in addition to those accounted for by the number of pregnancies.

\section{Comparisons with other studies}

The trajectory of bone growth has been suggested to be programmed during early life. ${ }^{2}$ Before adjustment for adult height and weight, our results for bone area confirm previous associations reported between birth weight and adult skeletal size. $^{32}$ This may account for previous reports of associations between birth or infant weight and bone mineral content, which is highly related to skeletal size, and have been shown

\section{Policy implications}

The link between fetal growth and future bone health seems to be mediated through achieved adult height and adult lifestyle. Promotion of a healthier adult lifestyle would seem to be the public health intervention most likely to reduce the risk of poor bone health in middle age. 
to disappear after correction for bone area. ${ }^{3}$ An association between birth weight or weight in infancy and bone mineral content has often been seen along with no association between early life and BMD, ${ }^{23}{ }^{30-32}$ although an association was present in a small number of studies. ${ }^{29}$ A recent twin study showed that birth weight was related to BMD, independently of maternal factors, but not independently of adult height and weight. ${ }^{29}$ An association between family position and bone health does not seem to have been previously reported.

Adult lifestyle factors such as smoking, diet, and physical activity are known to affect the rate of bone mineral loss and hence fracture risk. ${ }^{6}$ This is consistent with our results suggesting that adult lifestyle and body size are the important influences on bone health in middle age. Vitamin $\mathrm{C}$ has been postulated as the antioxidant most likely to have an influence on bone formation and bone loss. ${ }^{33}$ Previous studies have shown a relation between vitamin $\mathrm{C}$ intake and BMD in women, ${ }^{34-36}$ although often at older ages. The relation between vitamin C and BMD seen for the men in this investigation may be, at least in part, attributable to the limitations of dietary assessment.

It is also possible that some of the significant associations between explanatory variables and indicators of bone health are a consequence of the number of statistical models fitted or may reflect unmeasured confounding.

A relation between alcohol consumption and bone area does not seem to have been previously reported, although an association between moderate alcohol consumption and increased BMD has recently been suggested. ${ }^{37}$

In addition to bone size and density, future fracture risk is also dependent on bone geometry. Little is known as to which factors may influence femoral neck shaft angle.

\section{Conclusion}

Our findings suggest that, while birth weight does seem to influence skeletal growth, adult lifestyle and body size seem to be the most important determinants of bone health in middle age in this cohort. The previously observed effect of fetal life on bone health in adulthood may be mediated through adult height and weight.

\section{ACKNOWLEDGEMENTS}

We thank all the thousand family study members for taking part in this study and the study teams past and present. We thank the Wellcome Trust, the Minnie Henderson Trust, the Sir John Knott Trust, and the Special Trustees of the Newcastle Hospitals for funding. EPIC food frequency questionnaires were analysed by the MRC Dunn Human Nutrition Unit, Cambridge.

\section{Authors' affiliations \\ M S Pearce, F N Birrell, R M Francis, L Parker, School of Clinical} Medical Sciences, University of Newcastle upon Tyne, Sir James Spence Institute, Royal Victoria Infirmary, Newcastle upon Tyne, UK

D J Rawlings, Regional Medical Physics Department, Freeman Hospital, Newcastle upon Tyne, UK

S P Tuck, Musculoskeletal Unit, Freeman Hospital

Competing interests: none declared.

Ethical approval for the study was obtained from local research ethics committees and all participants gave their written informed consent.

\section{REFERENCES}

1 Barker DJP. The developmental origins of adult disease. Eur J Epidemiol 2003; 18:733-6.

2 Gale CR, Martyn CN, Kellingray S, et al. Intrauterine programming of adult body composition. J Clin Endocrinol Metabol 2001;86:267-72.

3 Cooper C, Fall C, Egger P, et al. Growth in infancy and bone mass in later life. Ann Rheum Dis 1997;56:17-21.

4 Oreffo RO, Lashbrooke B, Roach $\mathrm{HI}$, et al. Maternal protein deficiency affects mesenchymal stem cell activity in the developing offspring. Bone 2003;33:100-7.
5 Cooper C, Walker-Bone K, Arden N, et al. Novel insights into the pathogenesis of osteoporosis: the role of intrauterine programming Rheumatology 2000;39:1312-15.

6 Scane AC, Francis RM. Risk factors for osteoporosis in men. Clin Endocrinol 1993:38:15-16.

7 Lamont DW, Parker L, Cohen MA, et al. Early life and later determinants of adult disease: a 50 year follow-up study of the Newcastle thousand families cohort. Public Health 1998;112:85-93.

8 Gnudi S, Ripamonti C, Lisi L, et al. Proximal femur geometry to detect and distinguish femoral neck fractures from trochanteric fractures in postmenopausal women. Osteoporos Int 2002;13:69-73.

9 Kuh D, Ben Shlomo Y, Lynch J, et al. Life course epidemiology. J Epidemiol Community Health 2003;57:778-83.

10 Spence J, Walton WS, Miller FJW, et al. A thousand families in Newcastle upon Tyne. London: Oxford University Press, 1954.

11 Lamont D, Parker L, White M, et al. Risk of cardiovascular disease measured by carotid intima-media thickness at age 49-51: lifecourse study. BMJ 2000;320:273-8.

12 Quereshi AM, McGuigan FEA, Seymoor DG, et al. Association between COLIA1 Spi alleles and femoral neck geometry. Calcif Tissue Int 2001;69:67-72.

13 Faulkner KG, Bachrach LK, Carter DR, et al. Simple measurement of femoral geometry predicts hip fracture: the study of osteoporotic fractures. J Bone Miner Res 1993;8:1211-17.

14 Victora CG, Huttly SR, Fuchs SC, et al. The role of conceptual frameworks in epidemiological analysis: a hierarchical approach. Int J Epidemiol 1997;26:224-7.

15 Miller FJW, Court SDM, Walton WS, et al. Growing up in Newcastle upon Tyne. London: Oxford University Press, 1960.

16 Miller FJW, Court SDM, Knox EG, et al. The school years in Newcastle upon Tyne, 1952-62. London: Oxford University Press, 1974.

17 Freeman JV, Cole TJ, Chinn S, et al. Cross sectional stature and weight reference curves for the UK, 1990. Arch Dis Child 1995;73:17-24.

18 Must A, Phillips SM, Naumova EN, et al. Recall of early menstrual history and menarcheal body size: after 30 years, how well do women remember? Am J Epidemiol 2002;155:672-9.

19 Power C, Rodgers B, Hope S. U-shaped relation for alcohol consumption and health in early adulthood and implications for mortality. Lancet 1998;352:877.

20 Bingham SA, Gill C, Welch A, et al. Validation of dietary assessment methods in the UK arm of EPIC using weighed records, and 24-hour urinary nitrogen and potassium and serum vitamin $C$ and carotenoids as biomarkers. Int J Epidemiol 1997;26:S137-51.

21 Kuh DJL, Cooper C. Physical activity at 36 years: patterns and childhood predictors in a longitudinal study. J Epidemiol Community Health 1992;46:114-19.

22 Parker L, Lamont DW, Unwin N, et al. A lifecourse study of risk for hyperinsulinaemia, dyslipidaemia and obesity (the central metabolic syndrome) at age 49-51 years. Diabet Med 2003;20:406-15.

23 Cooper C, Eriksson JG, Forsen T, et al. Maternal height, childhood growth and risk of hip fracture in later life: a longitudinal study. Osteoporos Int 2001;12:623-9.

24 Royston P, Ambler G, Sauerbrei W. The use of fractional polynomials to model continuous risk variables in epidemiology. Int J Epidemiol 1999;28:964-74.

25 Hales CN, Barker DJP, Clark PMS, et al. Fetal and infant growth and impaired glucose tolerance at age 64. BMJ 1991;303:225-8.

26 Martyn CN, Hales CN, Barker DJP, et al. Fetal growth and hyperinsulinaemia in adult life. Diabet Med 1998; 15:688-94.

27 Pietinen P, Hartman AM, Haapa E, et al. Reproducibility and validity of dietary assessment instruments. I. A self-administered food use questionnaire with a portion size picture booklet. Am J Epidemiol 1988;128:655-66.

28 Andersen LF, Nes M, Lillegaard IT, et al. Evaluation of a quantitative food frequency questionnaire used in a group of Norwegian adolescents. Eur J Clin Nutr 1995;49:543-54.

29 Antoniades L, MacGregor AJ, Andrew T, et al. Association of birth weight with osteoporosis and osteoarthritis in adult twins. Rheumatology 2003;42:791-6.

30 Cooper C, Cawley M, Bhalla A, et al. Childhood growth, physical activity, and peak bone mass in women. J Bone Miner Res 1995;10:940-7.

31 Duppe H, Cooper C, Gardsell P, et al. The relationship between childhood growth, bone mass, and muscle strength in male and female adolescents. Calcif Tissue Int 1997;60:405-9.

32 Yarbrough DE, Barrett-Connor E, Morton DJ. Birth weight as a predictor of adult bone mass in postmenopausal women: the Rancho Bernardo study. Osteoporos Int 2000;11:626-30.

33 Maggio D, Barabani M, Pierandrei $M$, et al. Marked decrease in plasma antioxidants in aged osteoporotic women: results of a cross-sectional study. J Clin Endocrinol Metabol 2003;188:1523-7.

34 Hall SL, Greenslade GA. The relation of dietary vitamin C intake to BMD: results from the PEPI study. Calcif Tissue Int 1998;63:183-9.

35 Ilich JZ, Brownbill RA, Tamborini L. Bone and nutrition in elderly women: protein, energy and calcium as main determinants of BMD. Eur J Clin Nutr 2003:57:554-65.

36 Kaptoge S, Welch A, McTaggart A, et al. Effects of dietary nutrients and food groups on bone loss from the proximal femur in men and women in the 7th and 8th decades of age. Osteoporos Int 2003;14:418-28.

37 Williams FM, Cherkas LF, Spector TD, et al. The effect of moderate alcohol consumption on BMD: a study of female twins. Ann Rheum Dis 2005;64:309-10. 